\title{
THE SOLUTION FOR STUDY PROGRAMME LEARNING OUTCOME ALIGNMENT WITH STUDY COURSE LEARNING OUTCOME
}

\author{
Raita Rollande \\ Ventspils University of Applied Sciences, Latvia \\ Antons Mislevics \\ Riga Technical University, Latvia
}

\begin{abstract}
The research question of this paper is - How can we better help professors with developing course descriptions and how we can help study program directors to reach study program aims through learning outcomes? This issue is very common for all Latvian higher education institutions as well as other higher education institutions outside of Latvia. It became clear after reading the new changes of the Law of Higher Education of the Republic of Latvia that two major changes had to be made first in course descriptions: updating the course descriptions to the new requirements and creating a mapping of the study programs. The decision was made to start work on a Course Management System. The goal purpose was to create a Course Management System that will help professors with developing course descriptions and will help study program directors to reach study program aims through learning outcomes. At first together with students the authors did a detailed analysis of the system and then developed it. Now the system is ready for implementation. Thanks to the developed system at Ventspils University of Applied Sciences has solved several important issues related to the course descriptions.

For study programme learning outcome alignment with study course learning outcome will be used matrix method. CMS is web application what is developed using HTML, CSS, Javascript, and CSS frame Bootstrapare, PHP framework Laravel and MySQL.
\end{abstract}

Keywords: learning outcome, matrix method, study course management system, study programme development.

\section{Introduction}

This issue is very common for all Latvian higher education institutions as well as other higher education institutions outside of Latvia. For every institution of higher education not only in Latvia but also in other countries in the world the accreditation process is important. Accreditation is a type of quality assurance process with what programs are evaluated and verified by an external body to determine if the appropriate standards are met. Every higher education institution strives to show good results in obtaining a positive accreditation. In 2018 the Ministries of Education proposed new changes to the Law on Higher Education 
Institutions regarding accreditation of study fields (Latvijas Vēstnesis, 1995). One of the most important issues is the study program and study course learning outcomes - how study program learning outcomes are achieved through the study course learning outcomes. It became clear after reading the regulations that two major changes had to be made first: updating the course descriptions to the new requirements and creating a mapping of the study programs. If the course descriptions are not described then it is not possible to create a study program mapping. The professors filled the course description very slowly. After a year less than half of the course descriptions were designed in the new format. Other conclusion was that there was not only one place where all course descriptions are kept but many and course descriptions are formatted differently. To overcome these shortcomings, the decision was made to start work on a Course Management System (CMS). At first together with students was performed a detailed analysis of the system and then developed it using Agile Scrum methodology. Now the system is ready for implementation. Function of importing existing course description files was built into the system so that the work of the professors who had already developed the course descriptions was no for nothing. Thanks to the developed system at Ventspils University of Applied Sciences (VuAS) has solved several important issues related to the course descriptions and they are:

- Study program mapping is provided automatically.

- Study course descriptions are kept in one place.

- Users can access up-to-date study course descriptions.

- It is possible to retrieve study course descriptions at any time, for example to submit accreditations.

- You can retrieve information on the literature required for studying at the library.

- $\quad$ Students (both current and prospective) can obtain study course catalogs.

Since one of authors have been working as a study program accreditation expert for over 4 years, authors can conclude that the problem of study course descriptions and mapping of study program learning outcomes is very common for all Latvian higher education institutions. In the research authors have come up with a solution that can make work easier for higher education institutions and ensure higher quality of study.

The purpose of research is to create Course Management System that will help professors with developing course descriptions and will helps study program directors to reach study program aims through learning outcomes. 


\section{Literature review}

In every higher education institution quality assurance is a matter of concern. Since 2005 according to the Bologna process significant progress has been made in quality assurance - qualifications' framework, recognition and the promotion of the use of learning outcomes. All these factors contributed to a paradigm shift towards student-centered learning and teaching (BFUG Working Group on Qualifications Frameworks, 2007; European Students' Union, European University Association, European Association of Institutions in Higher Education, \& European Association for Quality Assurance in Higher Education, 2015). Study programmes and their components have to be designed in terms of learning outcomes: what students need to know, understand and be able to do by the end of the learning process (European Students' Union et al., 2015). The achievement of learning outcome has to be assessed through procedures based on clear and transparent criteria (European Higher Education Area, Bologna process, European Comission, 2015; European Union \& Education Audiovisual and Culture Executive Agency, 2018). Learning outcome (Damiani, 2019):

- $\quad$ implement a learner - centered approach in designing and delivering study programmes;

- make study programmes fully transparent;

- $\quad$ ensure the recognition of the learning achievements of mobile students.

The Law of Higher Education of the Republic of Latvia defines the learning outcome as "a set of knowledge, skills and competence to be acquired at the end of the study programme, study module or study course" (Latvijas Vēstnesis, 1995). The learning outcome is determined for study programs and study courses. Different methods may be used to demonstrate how the learning outcome of the study programme correlates with learning outcome of the study course. One of the most basic methods to reflect the relationship between study results is the matrix method. Many institutions use the matrix method for mapping the learning outcome of the study programme with those of its educational components (European Higher Education Area et al., 2015).

According to Latvian legislation higher education institutions in Latvia are required to use the matrix method (Figure 1) for study program mapping. 


\begin{tabular}{|c|c|c|c|c|c|c|c|c|c|c|}
\hline & & SP LO 1 & SP LO 2 & SP LO 3 & SP LO 4 & SP LO 5 & SP LO 6 & SP LO 7 & SP LO 8 & SPLO 9 \\
\hline \multirow{5}{*}{ 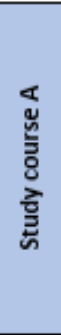 } & $\begin{array}{l}\text { Study course A } \\
\text { LO } 1\end{array}$ & $x$ & & & & & & & & $x$ \\
\hline & $\begin{array}{l}\text { Study course A } \\
\text { LO } 2\end{array}$ & $x$ & & & & & & & $x$ & \\
\hline & $\begin{array}{l}\text { Study course A } \\
\text { LO } 3\end{array}$ & & $x$ & & & & & & & \\
\hline & $\begin{array}{l}\text { Study course A } \\
\text { LO } 4\end{array}$ & & & & & $x$ & & $x$ & $x$ & \\
\hline & $\begin{array}{l}\text { Study course A } \\
\text { LO } 5\end{array}$ & & & & $x$ & & $x$ & & & \\
\hline \multirow{5}{*}{ 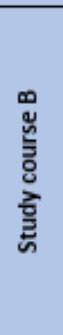 } & $\begin{array}{l}\text { Study course B } \\
\text { LO } 1\end{array}$ & & $x$ & & & & & & & \\
\hline & $\begin{array}{l}\text { Study course B } \\
\text { LO } 2\end{array}$ & $x$ & & & & & & & & \\
\hline & $\begin{array}{l}\text { Study course B } \\
\text { LO } 3\end{array}$ & & & & $x$ & & & & & \\
\hline & $\begin{array}{l}\text { Study course B } \\
\text { LO } 4\end{array}$ & & & & & $x$ & $x$ & & & \\
\hline & $\begin{array}{l}\text { Study course B } \\
\text { LO } 5\end{array}$ & & & & & & & $x$ & $x$ & \\
\hline 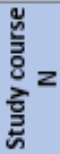 & $\begin{array}{l}\text { Study course N } \\
\text { LOM }\end{array}$ & & & & $x$ & & & & & \\
\hline
\end{tabular}

Abbreviations:

LO-learning outcome|

SP - study programme

Figure 1 Relationship of study programme learning outcome with study course learning outcome

It is very important to mention that the study course learning outcome can be defined in two ways:

- $\quad$ absolute (direct) relevance - in this way the learning outcome in the study programme is achieved through the study course learning outcome. The learning outcome is added/indicated from the list of learning outcomes to be achieved by the study programme (the user chooses the learning outcome from the list) (Figure 2).

- $\quad$ custom (related) relevance - which learning outcome in the study programme is achieved through the study course. In this case the learning outcome is added to the study course which is linked to one or more learning outcomes to be achieved by the study programme (Figure 3). 
SOCIETY. INTEGRATION. EDUCATION

Proceedings of the International Scientific Conference. Volume IV, May $22^{\text {th }}-23^{\text {th }}$, 2020. 612-621

\begin{tabular}{|c|c|c|c|c|c|c|c|c|c|c|c|}
\hline & \multicolumn{4}{|c|}{ Knowledge } & \multicolumn{3}{|c|}{ Skills } & \multicolumn{3}{|c|}{ Attitudes } \\
\hline & & KLO1 & KLO2 & KLO3 & KLOn & SLO1 & SKLO2 & SLOn & ALO1 & ALO2 & ALOn \\
\hline \multirow{5}{*}{ 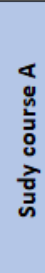 } & LO A1 & $\mathrm{x}$ & & & & & & & & & \\
\hline & LO A2 & & & & & & & & $\mathrm{x}$ & & \\
\hline & LO A3 & & $x$ & & & & & & & & \\
\hline & LO A4 & & & & & $\mathrm{x}$ & & $\mathrm{x}$ & $\mathrm{x}$ & & \\
\hline & LO AN & & & & $\mathrm{x}$ & & $\mathrm{x}$ & & & & \\
\hline \multirow{5}{*}{ 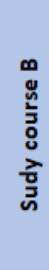 } & LO B1 & & $\mathrm{x}$ & & & & & & & & \\
\hline & LO B2 & & & & & & & & & & $\mathrm{x}$ \\
\hline & LO B3 & & & & $x$ & & & & & & \\
\hline & LO B4 & & & & & $x$ & $\mathrm{x}$ & & & & \\
\hline & LO BN & & & & & & & & $\mathrm{x}$ & & \\
\hline 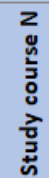 & LO NM & & & & $\mathrm{x}$ & & & & & & \\
\hline
\end{tabular}

Figure 2 Absolute (direct) relevance

\begin{tabular}{|c|c|c|c|c|c|c|c|c|c|c|}
\hline & \multicolumn{4}{|c|}{ Knowledge } & \multicolumn{3}{|c|}{ Skills } & \multicolumn{3}{|c|}{ Attitudes } \\
\hline & KLO1 & KLO2 & KLO3 & KLOn & SLO1 & SKLO2 & SLOn & ALO1 & ALO2 & ALOn \\
\hline SC 1 & $\mathrm{x}$ & & $x$ & & & $\mathrm{x}$ & $x$ & & & $x$ \\
\hline SC 2 & & & & & $x$ & & & $x$ & & \\
\hline SC 3 & & $x$ & & $x$ & & & & & $x$ & \\
\hline SC 4 & $x$ & $x$ & & & & $x$ & & & & $x$ \\
\hline SC 5 & $x$ & & $x$ & & & $\mathrm{x}$ & & $x$ & $x$ & $x$ \\
\hline SC 6 & & & & $x$ & $\mathrm{x}$ & $\mathrm{x}$ & & & & \\
\hline SC 7 & $x$ & $x$ & & & & & $x$ & $x$ & $x$ & \\
\hline SC 8 & & $x$ & $x$ & $x$ & $\mathrm{x}$ & & & & & \\
\hline SC 9 & & & & $\mathrm{x}$ & $\mathrm{x}$ & $x$ & $x$ & & & \\
\hline SC 10 & & $x$ & $x$ & & & & & $x$ & $x$ & \\
\hline $\mathrm{SCN}$ & & & & $x$ & $x$ & $x$ & & $x$ & $x$ & \\
\hline
\end{tabular}

Figure 3 Custom (related) relevance 
Rollande \& Mislevics, 2020. The Solution for Study Programme Learning Outcome Alignment with Study Course Learning Outcome

\section{Methodology}

To implement the content of the study program in accordance with its aim, the study program and course descriptions must describe the learning outcomes of the study program. The learning outcomes of each study course must be related to the learning outcomes of the study program. Learning outcomes of each study program can be achieved through several study course learning outcomes. In order to clearly and qualitatively describe the learning outcomes both for the study programme and for study courses, followed by the design of the mapping of the learning outcome. It is necessary to develop information systems for study program's learning outcome alignment with study course learning outcome. Such a system has been developed in Ventspils University of Applied Sciences.

The information system has been developed and implementation steps will be launched in 2020 (Figure 4). First we need to enter the basic data (information about faculty, study directions, study programs) into the system and then we have to start importing and editing data from prepared study course descriptions as well as entering new data of study courses. When data entry in the system is completed the mapping of learning outcomes will be generated and different course catalogues will be created. The expected result is that such information systems will under strict and uniform conditions store course descriptions and facilitate the development of learning outcome mapping and allow to create and publish course catalogues for different user groups. As a result Ventspils University of Applied Sciences will improve quality assurance: the process will continue further towards learning - centered approach in designing and delivering study programmes and increasing higher transparency of study programmes.
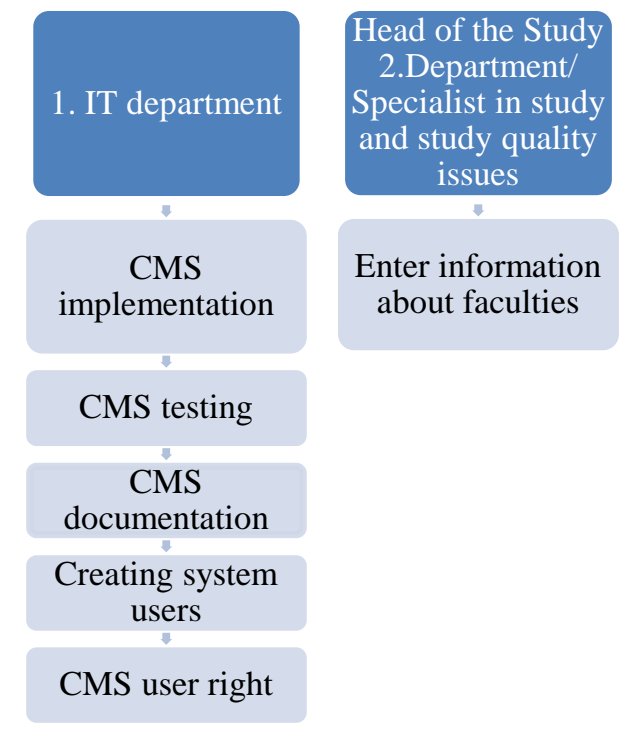

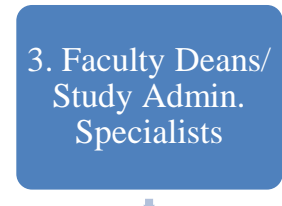

Enter information about study fields

Enter information about study program directors

Enter information about faculty staff

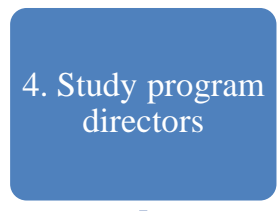

Enter information about study program

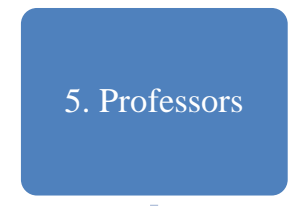

Enter study course description

Figure 4 CMS implementation steps 
SOCIETY. INTEGRATION. EDUCATION

Proceedings of the International Scientific Conference. Volume IV, May $22^{\text {th }}-23^{\text {th }}$, 2020. 612-621

\section{Research results}

The Course Management System is already created. The authors have been working with students on this system development since 2017. The information system is developed as a web application. HTML, CSS, Javascript, and CSS frame Bootstrapare used for client-side solution. PHP framework Laravel is chosen for the development of the system and framework`s. MySQL was used for database creation. The database architecture consists of 25 interrelated entities. CMS is developed using Agile Srum methodology (Tytkowska, Werner, \& Bach, 2015).

The main objective of the system is to ensure the storage and management of all study course descriptions. The definition of study course catalogues and the creation and presentation of an automatic study program and mapping of the study course learning outcome.

System functions: The system should ensure the addition, saving, editing, deleting, presentation and retrieving from database information about new faculty, study courses, study programmes, learning outcome derived achievable by study programmers. To make it easier to add new study courses users have the option to upload course description files. The system is reading the content of such files and filling the input fields needed to add a new course description. For each study programme the system will represent the mapping of study programme learning outcome. The system allows users to define (create new) study course catalogues by specifying their content and audience to view a list of course catalogues already stored in the system. You can also edit and delete catalogues. In Figure 5 is shown the main structure of CMS.
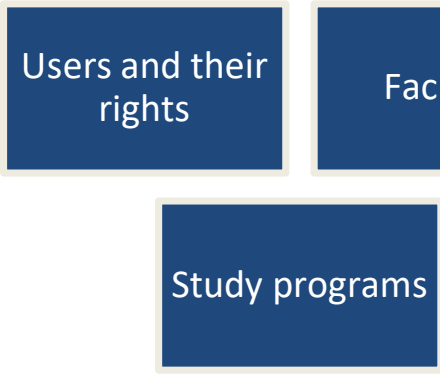
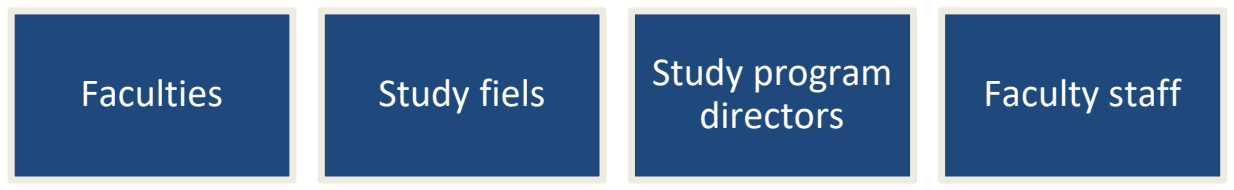

Study program mapping
Study program catalogs

Figure 5 CMS main structure

System users are divided into user groups according to their system usage permissions: Foreign Affairs Specialist, Potential students, Vice Rector for Studies, Students, Faculty Deans/Study Administration Specialists, Professors, Head of the Study Department/Specialist in study and study quality issues. In Figure 6 is shown all CMS users and their functions. 


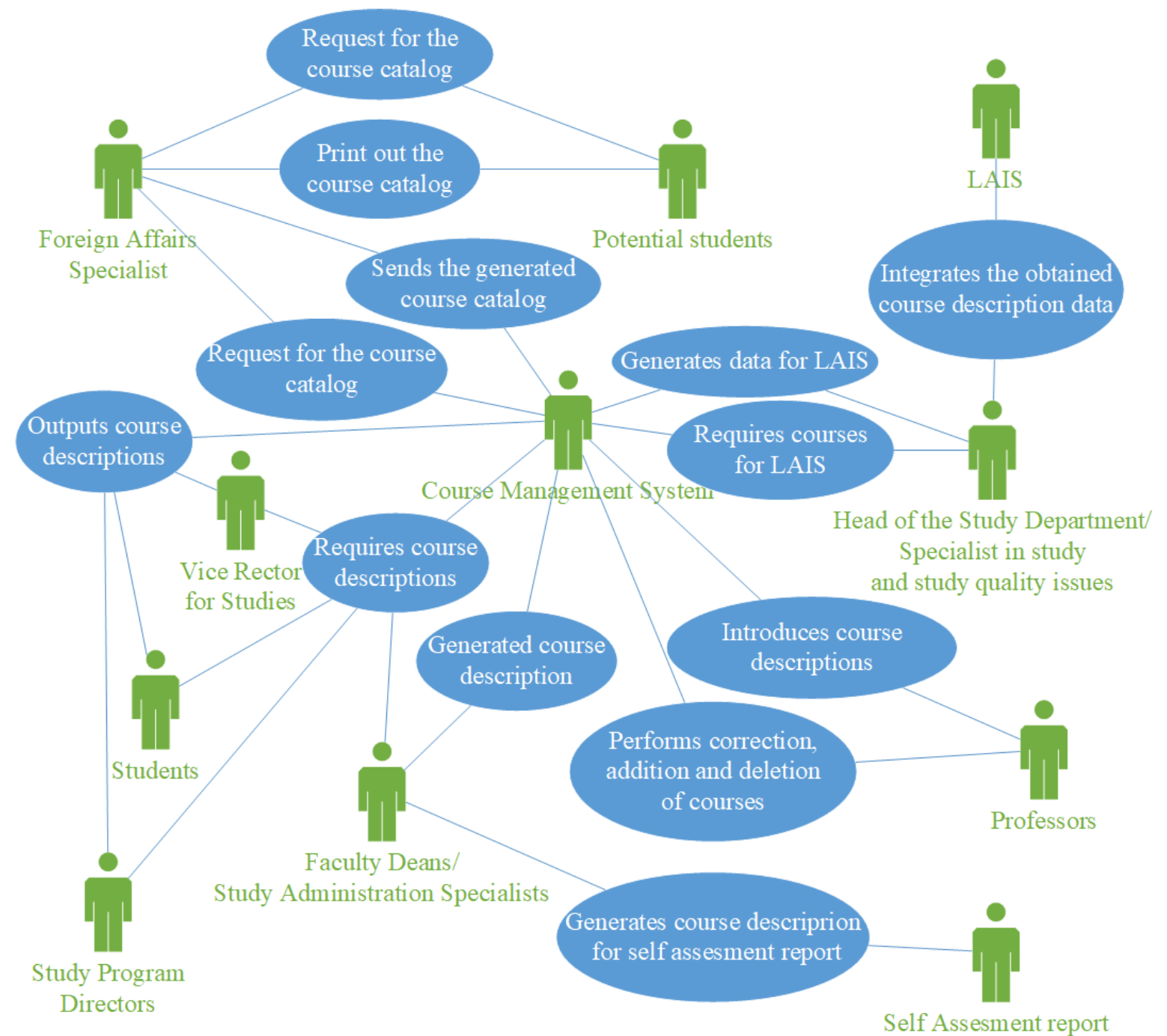

Figure 6 System users and their functions

\section{Conclusions}

CMS will help professors with developing course descriptions and help study program directors to reach study program aims through learning outcomes. On the one hand, this is a practical study with a practical result. The most valuable features we would like to emphasize are: importing course description files, generating course descriptions for Latvian Higher Education Institution Information System (LAIS), study program learning outcome mapping based on full or partial relevance of the course learning outcomes, and assigning ranks to the course outcomes.

Another function that authors plan to integrate into the CMS to control changes to the curriculum is to determine the significance of the courses in the curriculum. The content of the study program is changing; it is influenced by such 
conditions as changes in profession standards, labour market demand, etc. Changing the content of a study program is a natural process but it is very important to make it in accordance with the purpose of the study program. When making changes to the course descriptions one should not forget that through the study course learning outcomes the learning outcomes of the study program are achieved and thus the aim of the study program is achieved. Therefore it is very important to control that all study program outcomes are achieved. In order to control this, it is necessary to make a correlation between study courses and study program study results. As mentioned above it is most convenient to illustrate the relationship between the study program and the study courses in the form of a matrix, which is often done in practice. To determine the importance of each course in the study program, the authors suggest calculating the rankings for each study course link to the study program. Rank can be calculated by the local level of the node. To determine the rank of the elements of the local level, element input and output nodes have to be defined and after that the sum of input and output nodes is calculated by which the elements are ranked.

\section{Acknowledgements}

We would like to express our very great appreciation to students of bachelor study programme Computer Science of Ventspils University of Applied sciences for their valuable and constructive suggestions during the planning and development of CMS. We would also like to extend thanks to Mr. Endijs Mezitis for programming of CMS.

\section{References}

BFUG Working Group on Qualifications Frameworks. (2007). National Qualifications Frameworks Development and Certification. Report from Bologna Working Group on Qualifications Frameworks. (p. 51). Retrieved from http://www.aic.lv/bolona/ 2005_07/Reports/WGQF_rep_fin.pdf

Damiani, M.S. (2019, January 15). Implementation of the ECTS Users' Guide. Meeting of the Bologna Peer Support group: Qualifications Frameworks and ECTS. Retrieved from http://www.ehea.info/Upload/TPG_A_QF_RO_MK_1_ECTS.pdf

European Higher Education Area, Bologna process, \& European Comission. (2015). ECTS

Users' Guide 2015. Publications Office of the European Union. Retrieved from https://ec.europa.eu/education/sites/education/files/document-library-docs/ects-usersguide_en.pdf

European Students' Union, European University Association, European Association of Institutions in Higher Education, \& European Association for Quality Assurance in Higher Education. (2015). Standards and Guidelines for Quality Assurance in the European Higher Education Area (ESG). European Students' Union. 
Rollande \& Mislevics, 2020. The Solution for Study Programme Learning Outcome Alignment with Study Course Learning Outcome

European Union \& Education Audiovisual and Culture Executive Agency. (2018). The European higher education area in 2018: Bologna process implementation report. Publications Office of the European Union.

Latvijas Vēstnesis. (1995, December 1). Augstskolu likums. Likumi.lv. Pieejams https://likumi.lv/doc.php?id=37967

Tytkowska, M., Werner, A., \& Bach, M. (2015). Project Management in the Scrum Methodology. In S. Kozielski, D. Mrozek, P. Kasprowski, B. Małysiak-Mrozek, \& D. Kostrzewa (Eds.), Beyond Databases, Architectures and Structures (Vol. 521, pp. 483-492). Springer International Publishing. Retrieved from https://doi.org/10.1007/9783-319-18422-7_43 